\title{
Using of the Virtual Reality Application with the Scanning Device Kinect for Manufacturing Processes Planning
}

Jozef Novak-Marcincin, Veronika Fecova, Jozef Barna, Miroslav Janak, Ludmila Novakova-Marcincinova Faculty of Manufacturing Technologies, Technical University of Kosice, Bayerova 1, 08001 Presov, Slovak Republic

Introduction into problems - This article is focused on the area of virtual reality, in the concrete to the creation of application and its using. The applications are usually used with the expensive display devices and expensive motion tracking devices. For the application of virtual reality technology is currently available the several motion tracking devices, which have different prices. This contribution describes the using of application with the Kinect device, which is affordably priced. Kinect is a device that needn't for control any physical controller, because uses only the user's movements, which are transferred to the application. By using of virtual reality technology is very simply to compare the different versions of a solution and simply eliminate the found mistakes. And if the whole product design is proposed, controlled and simulated by using VR, in the production process should be no bigger problems.

Keywords: virtual reality, Kinect, motion tracking.

Acknowledgment

Ministry of Education of SR supported this work, contract VEGA No. 1/0032/12, KEGA No. 002TUKE-4/2012 and ITMS project 26220220125.

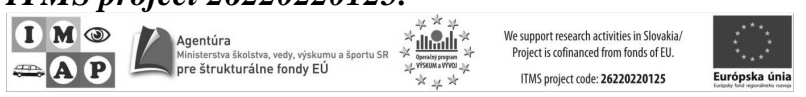

\section{References}

[1] NOVAK-MARCINCIN, J., JANAK, M., BARNA, J., TOROK, J., NOVAKOVA-MARCINCINOVA, L., FECOVA, V. (2012), Verification of a Program for the Control of a Robotic Workcell with the Use of AR. International Journal of Advanced Robotic Systems, Vol. 9, Aug 2012, p. 54-54, ISSN 1729-8806.

[2] NOVAK-MARCINCIN, J., DOLIAK, M., HLOCH, S., ERGIC, T. (2010), Application of the Virtual Reality Modelling Language to Computer Aided Robot Control System ROANS. Strojarstvo, Vol. 52, No. 2, p. 227-232, ISSN 0562-1887.

[3] NOVAK-MARCINCIN, J., BRAZDA, P., JANAK, M., KOCISKO, M. (2011), Application of Virtual Reality Technology in Simulation of Automated Workplaces. Tehnicki Vjesnik - Technical Gazette, Vol. 18, No. 4, pp. 577-580, ISSN 1330-3651.

[4] HUANG, CH. L., CHUNG, CH. Y. (2004). A Real-TimeModel-Based Human Motion Tracking and Analysis for Human Computer Interface Systems. Journal on Applied Signal Processing. No. 11, pp. 1648-1662.

[5] CHANG, I. CH., LIN, S. Y. (2012). 3D motion tracking based on a progressive particle filter. Pattern Recognition, Elsevier, Vol. 43.

[6] MIAW, D. R., RASKAR, R. (2009). Second Skin: Motion Capture with Actuated Feedback for Motor Learning. Spotlight on Works in Progress, Session 2, Boston, Massachusetts, USA, pp. 4537-4542.

[7] http://www.worldviz.com/products/vizard/index.html

[8] http://www.xbox.com/cs-CZ/Kinect/GetStarted

[9] FECOVA, V., NOVAKOVA-MARCINCINOVA, L., JANAK, M., NOVAK-MARCINCIN, J., BARNA, J. TOROK, J. (2012). Devices and software possibilities for using of motion tracking systems in the virtual reality system. 10th IEEE Jubilee International Symposium on Applied Machine Intelligence and Informatics, pp. 165168, ISBN 978-1-4577-0195-5.

[10] NOVAK-MARCINCIN, J., FECOVA, V., NOVAKOVA-MARCINCINOVA, L., JANAK, M., BARNA, J., KOCISKO, M. (2012), Virtools and its Application in MOCAP and Creation of the Scripts for Animations of Models. Engineering Review, Vol. 32, No. 2, p. 96-102, ISSN 1330-9587.

[11] NOVAK-MARCINCIN, J., BARNA, J., JANAK, M., NOVAKOVA-MARCINCINOVA, L., FECOVA, V. (2012). Production processes with integration of CA data in augmented reality environment, INES 2012 - 16th International Conference on Intelligent Engineering Systems, art. 6249806, p. 77-80, ISBN 978-146732695-7. 
[12] NOVAK-MARCINCIN, J., BARNA, J., JANAK, M., NOVAKOVA-MARCINCINOVA, L., TOROK, J. (2012) Visualization of intelligent assembling process by augmented reality tools application, LINDI 2012 - IEEE International Symposium on Logistics and Industrial Informatics, art. 6319505, p. 33-36, ISBN 978-146734519-4.

[13] BARNA, J., FECOVA, V., J. NOVAK-MARCINCIN, J., TOROK, J. (2012), Utilization of Open Source Application in Area of Augmented Reality Assembling Processes. Manufacturing Technology, Vol. 12, No. 12, p. 2-7, ISSN 1213-2489.

[14] NOVAK-MARCINCIN, J., NOVAKOVA-MARCINCINOVA, L., JANAK, M., FECOVA, V. (2012), Simulation of Flexible Manufacturing Systems for Logistics Optimization, LINDI 2012 - IEEE International Symposium on Logistics and Industrial Informatics, art. no. 6319506, p. 37-40, ISBN 978-146734519-4.

[15] KOCISKO, M., NOVAK-MARCINCIN, J., BARON, P., DOBRANSKY, J. (2012), Utilization of progressive simulation software for optimization of production systems in the area of small and medium companies. Tehnicki Vjesnik, Vol. 19, No. 4, pp. 983-986, ISSN 1330-3651.

[16] NOVAK-MARCINCIN, J., TOROK, J., BARNA, J., NOVAKOVA-MARCINCINOVA, L. (2012), Technology of Perspective Scanning Methods for Realization of 3D Models of Manufacturing Devices. Manufacturing Technology, Vol. 12, No. 13, pp. 186-191, ISSN 1213-2489. 